Article

\title{
Causality Effects among Gross Capital Formation, Unemployment and Economic Growth in South Africa
}

\author{
Michael Takudzwa Pasara ${ }^{1, *(1)}$ and Rufaro Garidzirai ${ }^{2}$ (1) \\ 1 Economic Sciences, North West University, Vanderbjilpark 1900, South Africa \\ 2 Management Sciences, Walter Sisulu University, Butterworth 4960, South Africa, rgaridzirai@wsu.ac.za \\ * Correspondence: michaelpasara@gmail.com
}

Received: 12 February 2020; Accepted: 26 March 2020; Published: 3 April 2020

check for updates

\begin{abstract}
Stagnant economic growth, decreasing investment and high unemployment remain consistent macroeconomic challenges for South Africa. Gross Capital formation (GCF) is designed to improve employment and economic growth (GDP). This study investigates the causality effects of the three variables using time series data from 1980 to 2018 in a Vector Autoregressive (VAR) framework. Results of the first model reveal a positive long-term relationship between gross capital formation GCF and economic growth GDP. Contrariwise, the first model indicates that unemployment (UNEMP) does not influence economic growth (GDP) in the short run. The second model results reveal a significant and positive relationship between UNEMP and GCF, while the third model shows an inverse relationship between GDP and UNEMP. Based on these findings, the study therefore recommends that fiscal authorities introduce expansionary fiscal policy that stimulates economic growth, investment and employment.
\end{abstract}

Keywords: unemployment; economic growth; capital formation; vector autoregressive; South Africa

\section{Introduction}

South Africa's socioeconomic challenges such as unemployment, poverty, stagnant growth and inequality are not a recent phenomenon. The country was facing these challenges as early as the 1980s when the country was operating under sanctions (du Plessis and Smit 2006). The unemployment and stagnant economic growth that have been persistent economic challenges in South Africa are notable. This is illustrated by an unemployment rate of 29 percent that is above the acceptable unemployment rate of 5 percent (Statistics South Africa 2018; Kimberly 2019). The augmented unemployment rate is a result of the apartheid policies that prevented the black majority from working (South Africa History Online 2019). Even after independence, the growth of job creation has not been fully provided for those who are willing to work. This further compromised economic growth that has been stagnant for almost a decade (Afolayan et al. 2019). Despite facing stagnant economic growth and unemployment, Taraki and Arslan (2019) emphasize that gross capital formation can create job opportunities, improving human capital and production. The authors further highlight that investors see more opportunities in an economy with high unemployment levels. Therefore, the relationship among unemployment, gross capital formation and economic growth has become a focus area for analysts and researchers (Statistics South Africa 2019; World Bank 2019).

The research problem of this study is twofold. The first research problem emanates from South Africa's stagnant economic growth and high unemployment rate. South Africa's economic growth has not fully recovered from the global financial crisis of 2008. From 2008, the economy has experienced three technical recessions (Statistics South Africa 2019). Currently, South Africa's economic 
growth is slightly above one percent. Furthermore, South Africa's unemployment rate keeps on increasing. The National Treasury (2019a) reports that the 29.1 percent increase, as of 2019, is the highest increase since 1900. In the face of these challenges, gross capital formation is expected to improve economic growth and employment in South Africa. The aforementioned variables are among the most widely used indicators in any economy and their importance cannot be overlooked.

The second research problem emanates from the existing literature on gross capital formation, unemployment and economic growth (Banda et al. 2016; Coffie 2018; Limosani and Monteforte 2017; Sahoo and Sahoo 2019; Makaringe and Khobai 2018). The aforementioned literature has bemoaned the absence of academic examination of unemployment, economic growth and gross capital formation relationships. Notably, the existing literature has been criticized for being infrequent and lacking adequate depth. In addition, there is no consensus on the association of the three economic indicators and to the knowledge of the authors, there is no study that examined all the three variables together. The lack of consensus creates a research gap that can be filled by the current study. Therefore, the objective of this study was to examine the nexus among economic growth, unemployment and gross capital formation in South Africa from 1980-2018 with the purpose of contributing to the body knowledge of macroeconomics.

\section{Stylized Facts about South Africa's Economy}

For the past years, employment and economic growth have been on the macroeconomic agenda of South Africa. The government has been struggling with these socioeconomic issues since the birth of the new South Africa. This is demonstrated by an average economic growth rate of 1.4 percent for the period 1980-1993, which was not good enough for economic development (Industrial Development Corporation 2013). Furthermore, unemployment was a prominent characteristic in the 1980s (Jones and Inggs 1994). The apartheid era made it difficult for the black majority to enter the labor market and this increased the unemployment rate. Due to a series of negotiations done in the early 1990s the African National Congress party formed a new government. Unfortunately, the new government inherited all these socioeconomic challenges (Department of Monitoring and Evaluation 2019).

In an attempt to eliminate unemployment and solve the stagnant economic growth, the government introduced a number of initiatives to this effect. These include the Accelerated and Shared Growth Initiative (ASIGISA), Reconstruction and Development Program (RDP) and the Growth, Employment, and Redistribution program (GEAR), to mention a few. These policies increased the average economic rate to 3.3 percent for the 1994-2012 period (National Treasury 2019b). This is a notable improvement compared to the 1.4 percent growth for the 1980-1993 period (Industrial Development Corporation 2013). It is also important to note that South Africa recorded its highest economic growth of 5.2 percent between 2004 and 2007 (Industrial Development Corporation 2013). This was attributed to competitive markets, thriving commodity prices and gross domestic capital formation. The gross domestic formation grew by 5.1 percent during the 1995-2004 period, thereby becoming the second contributor to economic growth (du Plessis and Smit 2006).

Since there was a substantial increase in economic growth, the unemployment rate was supposed to decrease. However, the formal sector failed to provide jobs and unemployment increased drastically (Mahadea and Simson 2010). This was witnessed in the construction, agriculture, mining and manufacturing sectors. There was uncertainty in these sectors, specifically in the agriculture sector. Uncertainty which caused economic shocks largely emanated from fear of land grabs, which directly affected the agriculture sector. This had ripple effects across sectors and many industries laid off workers (Altman 2013). As of today, the unemployment rate keeps on increasing and currently has increased from 27.6 percent to 29.1 percent (Statistics South Africa 2019). Analysts state that this is the highest increase in a decade and unemployment figures have been generally persistently high over three decades. Afolayan et al. (2019) forecast that an increase in unemployment is a threat to economic growth that has already been below 1 percent twice within two years. 


\section{Literature Review}

The study cannot be isolated from economic theories that link economic growth, gross capital formation and unemployment. The theories include the Keynesian, classical theories, Harrod-Domar theory and the balance theory of capital formation. The classical theory stipulates that any disturbance in an economy will automatically correct itself in the long-run (Edwards 1959). If the economy has high unemployment or stagnant economic growth, the classical economists propound that unemployment will disappear without using any policy (Chaudhary 1994; Limosani and Monteforte 2017). In the case of South Africa, the classical school of thought submits that apartheid policies, drought and any other shocks will automatically disappear, and the economy will revert to full employment. Contrary to the classical school of thought is the Keynesian theory that subscribes to the view that unemployment is caused by a lack of aggregate demand (Keynes 1936; Nikensari et al. 2019). Thus, authorities should make use of appropriate policies such as expansionary fiscal or monetary policy to deal with unemployment and a lack of economic growth. The proponents of this theory opine that unemployment is a result of misplaced policies, changing of economic structures and the lack of education that responds to the labor market (Banda et al. 2016; Wong et al. 2019).

Diverting from the classical and Keynesian school of thought is the Harrod-Domar theory. Harrod-Domar vehemently asserts that capital formation is the first step to economic growth and employment (Todaro and Smith 2006; Yoshino et al. 2019). The theory accentuates on the supply of capital in creating more income via the multiplier effect, thereby improving economic growth (Makris and Stavroyiannis 2019). Alternatively, the accumulation of capital increases production capacity, resulting in more people being employed and a reduction in the unemployment rate (Boianovsky 2015; Limosani and Monteforte 2017). Furthermore, the balanced theory of capital formation links the unemployment levels, economic growth and gross capital formation. This theory applies in developing countries that have lower economic growth and high population like South Africa (Taraki and Arslan 2019). The experts of the theory propound that the government should invest in industrial capital goods for production purposes (Krishna and Perez 2005). The capital goods should be spread out in all sectors for balanced growth in employment (Jhingan 2012). This will eventually improve economic growth and decrease the unemployment rate.

The relationship among unemployment, gross capital formation and economic growth cannot also be separated from other previous studies (Banda et al. 2016; Makaringe and Khobai 2018; Michael et al. 2016; Sahoo and Sahoo 2019; Saungweme et al. 2019). A study conducted in South Africa investigated the relationship between economic growth and unemployment between 1994 and 2012 (Banda et al. 2016). The study employed a Johansen cointegration and Vector Error Correction model and found a positive relationship between economic growth and unemployment. Thus, an increase in economic growth increases unemployment. Another study in South Africa by Makaringe and Khobai (2018) found contrary results to Banda et al. (2016), though the authors used the same variables and methodology. Makaringe and Khobai (2018) found an inverse relationship between unemployment and economic growth. This implies that an increase in economic growth creates more job opportunities and reduces unemployment in South Africa.

There are other studies that added more variables to economic growth and unemployment (examples include Alrayes and Wadi 2018; Bayar 2016; Sahoo and Sahoo 2019; Sahnoun and Abdennadher 2019; Ramudo et al. 2014). Alrayes and Wadi (2018) examined the determinants of unemployment in Bahrain. The study focused on economic growth, inflation, government expenditure and gross capital formation. The authors used a time series analysis and found that economic growth and inflation do not influence unemployment. Contrariwise, the study found a positive relationship between gross capital formation, government expenditure and unemployment. The same methodology and variables were used by Sahoo and Sahoo (2019) on a study conducted in India between 1991 and 2017. The results of the study reveal that economic growth and gross capital formation are positively related to unemployment. In Bahrain unemployment is not affected by the peaks and troughs in economic growth. However, 
in India the increase in economic growth also increases the unemployment rate. The results are different due to the economic policies used in each country.

In Zimbabwe, Saungweme et al. (2019) investigated the relationship between economic growth, formal employment, gross fixed formation and money supply. Formal employment was used as a dependent variable while economic growth, gross fixed formation and money supply were independent variables. The study employed the Ordinary Least Squares methodology and found that economic growth and gross capital formation positively influence formal employment. Therefore, an increase in economic growth in Zimbabwe creates more jobs while the buying of machinery in Zimbabwe expands production capacity that translates to formal job creation. The same results were obtained by Ramudo et al. (2014), though they used a structural VAR model. Contrary results were found by Suleiman et al. (2017) in Tanzania. The authors employed the dynamic ordinary least square (DOLS) methodology and concluded that economic growth and gross domestic formation are negatively related to employment in Tanzania. In other words, as economic growth and gross domestic formation increases, employment decreases. This was possibly due to the increase in investment which is attributed to large capital formation, a close substitute of labor according to the classical production function, which states that $[Q=f(L, K)]$. That is, output is a function of labor and capital.

Sahnoun and Abdennadher (2019) adopted a different stance by comparing developed and developing countries. The authors examined the relationship between unemployment and economic growth and looked at other variables such as government size, trade and inflation. The study used panel data and found that inflation, trade and economic growth are negatively related to unemployment in both developed and developing countries. The results imply that low inflation rate, an increase in trade activities and economic growth increases the chances of employing one individual in both developing and developed countries. In the same vein, a study in emerging countries has shown that gross domestic formation reduces the unemployment rate (Bayar 2016). The study used panel data between 2001 and 2014.

From the reviewed literature, there are conflicting views on the relationship among unemployment, economic growth and gross domestic formation. Some support a positive relationship among these variables, while others support a negative relationship among these variables. In addition, all these studies employed the Johansen Cointegration, Vector Error Correction Model, panel data analysis and the ordinary least square. According to the knowledge of the researchers, there is no study that has employed a VAR model. Therefore, this study employs a VAR model in analyzing the relationship among unemployment, economic growth and gross domestic formation. The next section discusses the methodology used in this study.

\section{Methodology}

\subsection{Model Specification and Methodology}

In examining the relationship among unemployment rate, economic growth and gross capital formation in South Africa the study used a quantitative analysis: Vector Autoregressive (VAR) model. The VAR model is preferred because it not only indicates the relationship between variables, but also provides some valuable information on causality (Gujarati 2004). VAR models are basically used to test interdependent relationships among variables. However, before employing the VAR model the unit root tests were performed using the Augmented Dickey Fuller (ADF) tests. Thus, all three variables: Gross Domestic Product (GDP), Gross Capital Formation (GCF) and Unemployment (UNEMP) were tested.

To minimize boundless degrees of freedom, the optimal lag length, $k$, was determined using both the Akaike Information Criterion (AIC) and the Schwartz Criterion (SC). It was predetermined by the authors if the two criterion do not concur, they would adopt the larger lag, although this may be done at the risk of misspecification errors or over-parameterized models (Gujarati 2004, p. 849. However, 
both the AIC and SC agreed for all three variables in the study. The following model specification was formulated:

$$
\begin{aligned}
& G D P_{t}=\gamma_{1}+\sum_{i=1}^{k} \alpha_{1 i} G D P_{t-i}+\sum_{i=1}^{k} \beta_{1 i} G C F_{t-i}+\sum_{i=1}^{k} \theta_{1 i} U N E M P_{t-i}+\mu_{1 t} \\
& G C F_{t}=\gamma_{2}+\sum_{i=1}^{k} \alpha_{2 i} G D P_{t-i}+\sum_{i=1}^{k} \beta_{2 i} G C F_{t-i}+\sum_{i=1}^{k} \theta_{2 i} U_{N E M P_{t-i}}+\mu_{2 t} \\
& \operatorname{UNEMP}_{t}=\gamma_{3}+\sum_{i=1}^{k} \alpha_{3 i} G D P_{t-i}+\sum_{i=1}^{k} \beta_{3 i} G C F_{t-i}+\sum_{i=1}^{k} \theta_{3 i} \operatorname{UNEMP}_{t-i}+\mu_{3 t}
\end{aligned}
$$

The variables GDP, GCF and UNEMP are as defined in the paragraph above while $\alpha, \beta$ and $\theta$ are the respective coefficients. $\mu$ represents white noise disturbances, which are also referred to as shocks in the language of VAR. $\gamma^{\prime}$ s are constants also referred to as drifts and $i=1 \ldots \ldots$ represent the length, with $k$ being the upper limit.

\subsection{Post Estimation Techniques}

After estimating the VAR, coefficient diagnostics were conducted using the Wald test. The purpose of the Wald test was to check parsimonious model (insignificant coefficients). Once insignificant coefficients are restricted, the parsimonious model was re-estimated. More diagnostic tests such as Durbin-Watson (DW) and Cholesky of covariance tests were performed to check the robustness of the model. Firstly, the serial correlation tests were conducted using the Durbin-Watson (DW) tests. A DW value of 2 indicates that there is no serial correlation. Secondly, heteroscedasticity tests were also performed, and results indicated that the model is not heteroskedastic given that the probability values were insignificant under a null hypothesis of homoscedasticity. Thirdly, normality tests were conducted using Cholesky of covariance, and all three components indicated that the residuals are normally distributed.

In addition to the VAR estimation, the paper also performs Variance Decomposition (VDC) analysis. VDC of forecast error shows the percentage of unexpected variation in each variable that is produced by shocks from other variables. In other words, VDC indicates the relative impact that a variable has on another and it enables the assessment of economic significance of the shock as a proportion of the forecast error for each variable.

\subsection{Explanation of Variables}

The paper employed GDP at constant 2010 prices to measure economic growth. GDP at constant prices measures both the size and the health of the economy and is used extensively in economic literature (Bandura and Dzingirai 2019). However, the variable does not indicate income distribution. However, this will not be of much concern since this study is not focusing on inequality issues but rather macroeconomic variations. The second variable is Gross Capital Formation (GCF) which was formerly referred to in several economic literature studies as the investment variable. Several studies concur that GCF is the most significant and yet the most volatile contributor of economic growth. Thus, analyzing this variable will give us an indication on the extent of its significance to South African growth and unemployment. The third variable is unemployment which is a percentage of the total labor force as modeled by the International Labor Organization (ILO).

The apriori expectation is that there is a positive relationship between GDP and GCF whilst there is an inverse relationship between GDP and unemployment. The rationale is that as an economy grows, it is likely to attract new investment and existing investments are also likely to be retained. On the other hand, as the economy grows, unemployment will likely decrease as more labor will be absorbed into the system. However, growth can occur due to other reasons such as increases in productivity as a result of technological inventions and innovations, ceteris paribus. Thus, the relationship is not 
always direct and should be investigated, especially with the rise of the fourth industrial revolution (4IR). However, the VAR model will not only inform us of whether relationships exists but will also indicate for how long the relationships will exist, that is, whether they exist in the short or long run.

\section{Empirical Results}

In terms of stationarity, the Augmented Dickey Fuller (ADF) results indicate that Gross Capital Formation (GCF) is stationary in levels whilst Gross Domestic Product (GDP_C) at constant 2010 prices and Unemployment (UNEMP) are stationary in first difference. These results are shown in Table 1.

Table 1. Augmented Dickey Fuller (ADF) unit root test.

\begin{tabular}{cccc}
\hline Variable & T-Stats & Prob & Decision \\
\hline GCF & -3.0084 & 0.4310 & \\
D(GCF) & -3.8376 & $0.0431^{* *}$ & $1(1)$ \\
GDP_C & -4.4390 & 0.5201 & \\
D(GDP_C $)$ & -4.5557 & $0.0001^{* * *}$ & $1(1)$ \\
UNEMP & -3.6909 & 0.1110 & $1(1)$ \\
D(UNEMP) & -3.9609 & $0.0013^{* * *}$ & \\
Note: ** and ${ }^{* * *}$ represents $5 \%$ and $1 \%$ significance level, respectively.
\end{tabular}

The table below provides some analysis from the Granger causality tests. The Granger causality test was employed to check if the macroeconomics values explain each other. Such a relationship was performed under the Vector Autoregressive (VAR) framework. A null hypothesis of no Granger causality was set and the results are reported in Table 2. The study results illustrate that GCF and UNEMP does not Granger cause GDP_C since their probability values are more than 0.10 percent. Conversely, GDP_C was found to Granger cause GCF as it rejected the null hypothesis of no Granger causality while UNEMP did not Granger cause GCF. Furthermore, the study illustrates that GDP_C and GCF Granger cause UNEMP. In other words, there is a unidirectional relationship between GDP and GCF, GCF and unemployment as well as GDP and unemployment, while no causal effects exist in the other combinations of relationships.

Table 2. Granger Causality Test.

\begin{tabular}{ccccc}
\hline Null Hypothesis & F-Statistic & Prob Value & Decision & Conclusion \\
\hline GDP does not Granger cause GCF & 6.0483 & $0.0486^{* *}$ & Reject & GDP $\rightarrow$ GCF \\
\hline UNEMP does not Granger GCF & 1.4873 & 0.4754 & Do not reject & No causality \\
\hline GCF does not Granger cause GDP & 2.5986 & 0.2727 & Do not reject & No causality \\
\hline UNEMP does not Granger cause GDP & 2.0163 & 0.3649 & Do not reject & No causality \\
\hline GCF does not Granger cause UNEMP & 10.5977 & $0.0050^{* * *}$ & Reject & GCF $\rightarrow$ UNEMP \\
\hline GDP does not Granger cause UNEMP & 15.9659 & $0.0003^{* * *}$ & Reject & GDP $\rightarrow$ UNEMP \\
\hline
\end{tabular}

Note: ${ }^{* *}$ and ${ }^{* * *}$ represents $5 \%$ and $1 \%$ significance level, respectively.

In terms of optimal lag length, this study employed the majority approach. Thus, the five criteria under consideration (shown in Tables A1-A3 in Appendix A) are the sequential modified LR test statistic (LR), the Final Prediction Error (FPE), Akaike Information Criterion (AIC), Schwarz Information Criterion (SIC) and the Hannan-Quinn Information Criterion (HQ). All five criteria indicate that the optimal lag length for GCF is one and all five also indicate that the optimal lags for GDP_C is two. Three out of five criteria (FPE, AIC \& HQ) indicate that one is the optimal lag length for GDP and GCF, while the optimal lag length for UNEMP is two. Thus, we run an unrestricted VAR model estimated as:

(1) $\mathrm{GDP} \_\mathrm{C}=\mathrm{C}(1)$ * GDP_C $(-1)+\mathrm{C}(2)$ * GDP_C $(-2)+\mathrm{C}(3)$ * $\mathrm{GCF}(-1)+\mathrm{C}(4)$ * $\mathrm{GCF}(-2)+\mathrm{C}(5)$ * $\operatorname{UNEMP}(-1)+\mathrm{C}(6) * \operatorname{UNEMP}(-2)+\mathrm{C}(7)$ 
(2) $\mathrm{GCF}=\mathrm{C}(8)$ * GDP_C $(-1)+\mathrm{C}(9)$ * GDP_C $(-2)+\mathrm{C}(10) * \mathrm{GCF}(-1)+\mathrm{C}(11) * \mathrm{GCF}(-2)+\mathrm{C}(12)$ * $\operatorname{UNEMP}(-1)+\mathrm{C}(13) * \operatorname{UNEMP}(-2)+\mathrm{C}(14)$

(3) $\mathrm{UNEMP}=\mathrm{C}(15) *{ }^{\mathrm{GDP}} \mathrm{C}(-1)+\mathrm{C}(16) *{ }^{*} \mathrm{GDP} \_\mathrm{C}(-2)+\mathrm{C}(17) * \mathrm{GCF}(-1)+\mathrm{C}(18) * \mathrm{GCF}(-2)+\mathrm{C}(19)$ * $\operatorname{UNEMP}(-1)+\mathrm{C}(20) * \mathrm{UNEMP}(-2)+\mathrm{C}(21)$

The results of the first unrestricted VAR model which is run with an optimal of two lags indicate that there are 21 coefficients which were estimated and only ten are significant, suggesting that the model is over-parameterized. Thus, we conducted a Wald test to observe which coefficients do not add value to the model. The results indicate that five coefficients are insignificant and are therefore removed from the model to make it parsimonious. Thus the removed coefficients are $C(3), C(6), C(9)$, $C(19)$ and $C(20)$. After removing these variables, the number of significant variables improved from 10 out of 21 to 13 out of 15 coefficients. A further attempt to remove additional insignificant variables reduced the number of significant variables to 10, suggesting that these variables have some input into the significant variables. Thus, the parsimonious model is presented below in Table 3 .

However, before proceeding to discussion of results, diagnostic tests were conducted under the null of no heteroskedasticity. Results indicate a probability value of 0.4144 , thereby implying that there is no heteroskedasticity. In terms of serial correlation, the Durbin-Watson results for the three equations are 1.85, 2.04 and 1.91, all of which are within the range of $|\mathrm{DW}|=2$. Thus, the error terms are not serially correlated. Normality tests were also conducted using Cholesky (Lutkepohl) orthogonalization and the results indicate $p$-values of 0.1130 for model 1; 0.1913 for model 2 and 0.8486 for model 3 . Thus, the normality tests indicate that all three components of the VAR are normally distributed. The results presented in Table 3 are therefore interpreted and discussed. However, the unrestricted VAR results will be discussed concurrently with the variance decomposition results, since they are interrelated.

Table 3. Regression results.

\begin{tabular}{ccccc}
\hline & Coefficient & Std. Error & t-Statistic & Prob. \\
\hline $\mathrm{C}(1)$ & 1.384026 & 0.191370 & 7.232187 & $0.0000^{* * *}$ \\
\hline $\mathrm{C}(2)$ & 0.433477 & 0.215480 & 2.011680 & $0.0494^{* *}$ \\
\hline $\mathrm{C}(4)$ & $1.73 \times 10^{10}$ & $7.63 \times 10^{9}$ & 2.274634 & $0.0270^{* *}$ \\
\hline $\mathrm{C}(5)$ & $9.62 \times 10^{9}$ & $6.47 \times 10^{9}$ & 1.485585 & 0.1433 \\
\hline $\mathrm{C}(7)$ & $-5.78 \times 10^{11}$ & $3.23 \times 10^{11}$ & -1.791818 & $0.0789^{*}$ \\
\hline $\mathrm{C}(8)$ & $1.51 \times 10^{-11}$ & $3.91 \times 10^{-12}$ & 3.858151 & $0.0003^{* * *}$ \\
\hline $\mathrm{C}(10)$ & 0.841170 & 0.279262 & 3.012112 & $0.0040^{* * *}$ \\
\hline $\mathrm{C}(11)$ & 0.411401 & 0.297078 & 1.384827 & 0.1719 \\
\hline $\mathrm{C}(12)$ & 0.486177 & 0.272246 & 1.785805 & $0.0799^{*}$ \\
\hline $\mathrm{C}(13)$ & 0.232215 & 0.202551 & 1.146454 & 0.2568 \\
\hline $\mathrm{C}(14)$ & -28.60477 & 12.71548 & -2.249602 & $0.0287^{* *}$ \\
\hline $\mathrm{C}(15)$ & $-2.38 \times 10^{-11}$ & $5.95 \times 10^{-12}$ & -4.003545 & $0.0002^{* * *}$ \\
\hline $\mathrm{C}(16)$ & $1.40 \times 10^{-11}$ & $6.48 \times 10^{-12}$ & 2.157581 & $0.0355^{* *}$ \\
\hline $\mathrm{C}(17)$ & -0.863644 & 0.182714 & -4.726752 & $0.0000^{* * *}$ \\
\hline $\mathrm{C}(18)$ & -0.298556 & 0.178035 & -1.676953 & $0.0994^{*}$ \\
\hline $\mathrm{C}(21)$ & 52.33543 & 2.787683 & 18.77381 & $0.0000^{* * *}$ \\
\hline & & & & \\
\hline
\end{tabular}

To get a proper comprehension for the rest of the variables, $C(1), C(2), C(3) \ldots C(21)$ are related to, kindly refer to the three estimated VAR equations above. The results indicate that previous levels of national wealth (lagged GDP) in both periods 1 and 2 are significant and positively related to 
GDP. Gross capital formation only influences GDP in period 2, suggesting that investment levels have a long-term effect in the South African economy. This is consistent with several investment theories/models such as Harrod-Domar and the balanced theory of capital formation. However, the first model indicates that unemployment does not influence gross domestic product in the short run. This probably indicates that South Africa is a capital-intensive economy and this trend is likely to continue, given that the general government policy is now skewed towards promoting the fourth industrial revolution (4IR).

Results from the second model which estimated gross capital formation indicates that lagged GDP is only significant in period 1 but not in the second. Similar results were also observed for lagged GCF as well which is significant and positively correlated in the first period. Unemployment levels in both periods also have a significant and positive influence on investment levels. This is possibly because investors find economies with high unemployment to have higher prospects for cheap labor (Taraki and Arslan 2019).

Unlike the first model where unemployment did not significantly influence the level of GDP, the opposite is not similar. In the third model, the level of GDP in both periods significantly influences the level of unemployment. Thus, economic growth is an integral part in reducing unemployment levels. This is consistent with the classical production function which states that output is a function of labor and capital $[Y=f(L, K)]$, and labor is easily substitutable in the short run. Similar results were also observed for gross capital formation, which have a significant effect on unemployment levels and the sign is negative, indicating the degree of substitutability between labor and capital.

Of note are the negative signs shown in the model for $C(15)$, which reflect an inverse relationship between unemployment (UNEMP) and gross domestic product (GDP_C) and for C(17) and C(18) which also reflect the inverse relationship between unemployment (UNEMP) and gross capital formation (GCF). Although these signs are negative, $\mathrm{C}(14)$ is a constant, so it is not a cause for concern. The only cause for concern is the negative sign for $\mathrm{C}(2)$, which shows some negative relationship between previous GDP in the previous two periods (GDP_C(-2)) and the current period. However, as shall be shown in the VDC results below, the influence of GDP on itself decreases over time, though not by higher margins. Otherwise the model has expected signs and results are sufficient enough to warrant reliable analysis. The results in Table 3 above are also similar to the results reflected in the Variance Decomposition (VDC) in Table 4 below. The VDC results give more information in terms of time trends as opposed to level significance levels as reflected in the table above. The authors would like to note that only five years were displayed in the tables below. However, reliable inferences can be made from the displayed results.

The results in Table 4 indicate that the standard errors (SE) are steadily increasing from the first year to the fifth year plausibly due to uncertainty effects over time. The VDC also indicates that that there is no variable which is purely exogenous or self-explained, since neither of the variables explain $100 \%$ of their innovations or shocks in period 5. More specifically, the forecast error variance for gross domestic product, gross capital formation and unemployment are $83.72 \%, 34.06 \%$ and $32.5 \%$, respectively.

Table 4 indicates that both gross capital formation (GCF) and unemployment (UNEMP) gradually affect the gross domestic product (GDP_C) over time. Interestingly, gross domestic product is completely exogenous in the first year, but the influence of the other variables is felt as time progresses. Specifically, $7.5 \%$ and $8.8 \%$ of GDP_C forecast error variance in a five-year period is explained by disturbances in gross capital formation and unemployment. Thus, GCF and UNEMP have long run effects on GDP. In other words, the current gross domestic product is explained by past levels in gross capital formation and unemployment, especially as more period years are included. 
Table 4. (a) Variance decomposition of GDP_C; (b) Variance decomposition of GCF. (c) Variance decomposition of UNEMP.

\begin{tabular}{|c|c|c|c|c|}
\hline Period & S.E. & GDP_C & GCF & UNEMP \\
\hline \multicolumn{5}{|c|}{ (a) } \\
\hline 1 & $2.82 \times 10^{10}$ & 100.0000 & 0.000000 & 0.000000 \\
\hline 2 & $5.13 \times 10^{10}$ & 96.32309 & 0.004387 & 3.672520 \\
\hline 3 & $6.39 \times 10^{10}$ & 92.57176 & 1.405464 & 6.022771 \\
\hline 4 & $7.11 \times 10^{10}$ & 88.34711 & 4.336666 & 7.316227 \\
\hline 5 & $7.71 \times 10^{10}$ & 83.71522 & 7.457550 & 8.827227 \\
\hline \multicolumn{5}{|c|}{ (b) } \\
\hline 1 & 0.901144 & 3.048627 & 96.95137 & 0.000000 \\
\hline 2 & 1.104069 & 10.08788 & 80.96059 & 8.951530 \\
\hline 3 & 1.433226 & 24.54669 & 52.60623 & 22.84708 \\
\hline 4 & 1.667475 & 34.09283 & 38.86514 & 27.04203 \\
\hline 5 & 1.793927 & 39.70213 & 34.06348 & 26.23439 \\
\hline \multicolumn{5}{|c|}{ (c) } \\
\hline 1 & 0.871719 & 5.463201 & 33.41597 & 61.12083 \\
\hline 2 & 1.198350 & 22.06904 & 45.47868 & 32.45228 \\
\hline 3 & 1.769492 & 36.05581 & 36.81638 & 27.12781 \\
\hline 4 & 2.230080 & 40.50636 & 28.56820 & 30.92543 \\
\hline 5 & 2.528498 & 44.30402 & 23.19614 & 32.49984 \\
\hline
\end{tabular}

Note: S. E= Standard Errors, GDP_C is Gross Domestic Product at constant prices, GCF is the Gross Capital Formation and UNEMP is Unemployment.

Table 4 shows that, by Period 5, approximately $40 \%$ of shocks in GCF are attributed to GDP_C while $26 \%$ are explained by changes in unemployment while the remaining $34 \%$ of shocks will still be attributable to shocks within the GCF variable itself. Thus, the effects of the size of the economy and the levels of unemployment on investment levels are more apparent both in the shorter time periods and longer time periods, since the changes from period 1 to period 5 are reasonably substantial.

Table 4 indicates that innovations in unemployment are mainly due to gross capital formation and unemployment itself in the short periods. However, they gradually decrease as more time passes, as shown by influences of $33 \%$ and $61 \%$, respectively, and in period 1 . Furthermore, the influence of the size of the economy, that is, gross domestic product become more substantial over longer periods as reflected by a $44 \%$ influence in period 5 compared to only $5 \%$ in period 1 . This implies that gross domestic product plays a more significant role in explaining unemployment over longer periods, while investment levels are more influential in shorter time periods. The graphs for impulse response functions were not shown, as the authors deem that they do nothing more than just providing a complementary function to the discussed results in the VDC above.

\section{Conclusions}

The purpose of the study was to examine the casual relationship among unemployment, economic growth and gross capital formation in South Africa during 1980-2018. The research problem was twofold. The first part emanates from the economic challenges of stagnant economic growth and unemployment, while the second is scarcity of literature on the aforementioned variables. Despite these challenges, the gross capital formation is envisaged to improve unemployment and economic growth. To test this hypothesis, the study employed time series analysis (granger causality analysis) and 
its associated VAR model. The results of the study revealed that gross capital formation positively influence unemployment and economic growth. Thus, the gross capital formation was seen as a catalyst for both employment and economic growth. On the other hand, unemployment levels did not influence economic growth, which was the expected result. The Granger causality results further confirm that economic growth causes gross capital formation. Simply put, economic growth improves the investment level in South Africa. Furthermore, the Granger causality results illustrate that GDP_C and GCF granger cause UNEMP. Based on these findings, the study therefore recommends that fiscal authorities introduce expansionary fiscal policy that stimulate economic growth, investment and employment. The government should spend more on capital goods to create employment and improve economic growth. Although the study achieved its aim, the study identified some limitations. The VAR methodology is not accommodative of additional variables such as inflation, government expenditure and trade, which could enrichen the discussion. However, these variables can be incorporated in the future studies which may be interested in related studies, although different methodologies will then have to be applied.

Author Contributions: The authors contributed equally to this work. The authors are grateful to the anonymous reviewers for their suggestions in improving the manuscript. All authors have read and agreed to the published version of the manuscript.

Funding: No funding was received.

Conflicts of Interest: The authors declare no conflict of interest

\section{Appendix A}

Table A1. GCF.

\begin{tabular}{ccccccc}
\hline Lag & LogL & LR & FPE & AIC & SC & HQ \\
\hline 0 & -90.05620 & NA & 8.037298 & 4.921957 & 4.965495 & 4.937306 \\
1 & -67.87763 & $41.95946^{*}$ & $2.558440 *$ & $3.777169^{*}$ & $3.864246^{*}$ & $3.807868^{*}$ \\
2 & -67.39066 & 0.894970 & 2.631043 & 3.804901 & 3.935516 & 3.850949 \\
\hline
\end{tabular}

* indicates lag order selected by the criterion; LR: sequential modified LR test statistic (each test at $5 \%$ level); FPE: Final prediction error; AIC: Akaike information criterion; SC: Schwarz information criterion; HQ: Hannan-Quinn information criterion.

Table A2. GDP_C.

\begin{tabular}{ccccccc}
\hline Lag & LogL & LR & FPE & AIC & SC & HQ \\
\hline 0 & -80.12097 & NA $^{*}$ & 4.697609 & 4.384918 & $4.428456^{*}$ & 4.400267 \\
1 & -78.33327 & 3.382138 & $4.502206^{*}$ & $4.342339^{*}$ & 4.429416 & $4.373038^{*}$ \\
2 & -77.72505 & 1.117812 & 4.599723 & 4.363516 & 4.494131 & 4.409564 \\
\hline
\end{tabular}

* indicates lag order selected by the criterion; LR: sequential modified LR test statistic (each test at $5 \%$ level); FPE: Final prediction error; AIC: Akaike information criterion; SC: Schwarz information criterion; HQ: Hannan-Quinn information criterion.

Table A3. UNEMP.

\begin{tabular}{ccccccc}
\hline Lag & LogL & LR & FPE & AIC & SC & HQ \\
\hline 0 & -59.55287 & NA & 9.099719 & 5.046072 & 5.095158 & 5.059095 \\
1 & -40.82861 & $34.32780 *$ & 2.078323 & 3.569051 & $3.667222 *$ & 3.595096 \\
2 & -39.62518 & 2.106004 & $2.045282 *$ & $3.552098^{*}$ & 3.699355 & $3.591166^{*}$ \\
\hline
\end{tabular}

* indicates lag order selected by the criterion; LR: sequential modified LR test statistic (each test at $5 \%$ level); FPE: Final prediction error; AIC: Akaike information criterion; SC: Schwarz information criterion; HQ: Hannan-Quinn information criterion. 


\section{References}

Afolayan, Olufunmilayo T., Henry Okodua, Oluwatoyin Matthew, and Romanus Osabohien. 2019. Reducing Unemployment Malaise in Nigeria: The Role of Electricity Consumption and Human Capital Development. International Journal of Energy Economics and Policy 9: 63-73. [CrossRef]

Alrayes, Sara E., and Rami Mohammad A. Wadi. 2018. Determinants of Unemployment in Bahrain. International Journal of Business and Social Science 9: 64-74. [CrossRef]

Altman, Miriam. 2013. The state of employment and unemployment in South Africa. Available online: www.hsrcpress.ac.za (accessed on 12 July 2019).

Banda, Handson, Hlanganipai Ngirande, and Fortune Hogwe. 2016. The impact of economic growth on unemployment in South Africa: 1994-2012. Investment Management and Financial Innovations 13: $246-55$. [CrossRef]

Bandura, Witness Nyasha, and Canicio Dzingirai. 2019. Financial development and economic growth in Sub-Saharan Africa: The role of institutions. PSL Quarterly Review 72: 315-34.

Bayar, Yilmaz. 2016. Financial Development and Unemployment in Emerging Market Economies. Scientific Annals of Economics and Business 63: 237-45. [CrossRef]

Boianovsky, Mauro. 2015. Beyond capital fundamentalism: Harrod, Domar and the history of development economics. Cambridge Journal of Economics 42: 477-504. [CrossRef]

Chaudhary, Mohamed A. 1994. Foreign Debt, Dependency, and Economic Growth in South Asia. The Pakistan Development Review 39: 551-70. [CrossRef]

Coffie, William. 2018. Modeling and forecasting volatility of the Botswana and Namibia stock market returns: Evidence using GARCH models with difference distribution densities. Global Business and Economics Review 20: 18-35. [CrossRef]

Department of Monitoring and Evaluation. 2019. Economic Transformation, Inclusive Growth, and Competitiveness: Towards an Economic Strategy for South Africa. Pretoria: Government Press.

du Plessis, Stan, and Ben Smit. 2006. Economic Growth in South Africa since 1994. Stellenbosch Working Paper Series No. WP01/2006. Stellenbosch: Economic Research Southern Africa. [CrossRef]

Edwards, Edgar O. 1959. Classical and Keynesian Employment Theories: A Reconciliation. Quarterly Journal of Economics 73: 407-28. [CrossRef]

Gujarati, Damodar N. 2004. Basic Econometrics, 4th ed. New York: McGraw-Hill Companies.

Industrial Development Corporation. 2013. South African Economy: An Overview of Key Trends Since 1994. Gauteng: Industrial Development Corporation.

Jhingan, Mohamed. 2012. The Economics of Development and Planning, 40th ed. Delhi: Vrinda Publications (P) Ltd., vol. 28.

Jones, Staurt, and Jon Inggs. 1994. An overview of the South African economy in the 1980s. South African Journal of Economic History 9: 1-18. [CrossRef]

Keynes, John M. 1936. The General Theory of Employment, Interest and Money. Cambridge: Cambridge University Press.

Kimberly, Amadeo. 2019. Economic Growth, Its Measurements, Causes, and Effects. Available online: https: //www.thebalance.com/what-is-economic-growth-3306014 (accessed on 1 November 2019).

Krishna, Kala, and Ceaser A. Perez. 2005. Unbalance Growth. Canadian Journal of Economics 38: 832-51. [CrossRef]

Limosani, Michele, and Fabio Monteforte. 2017. Increasing returns and unemployment: An assessment of their relative importance in structural change. International Journal of Economic Policy in Emerging Economies 10: 129-52. [CrossRef]

Mahadea, Darma, and Richard Simson. 2010. The challenge of low employment economic growth in South Africa: 1994-2008. South African Journal of Economics and Management 13: 391-406. [CrossRef]

Makaringe, Sibusiso C., and Hlalefang Khobai. 2018. The Effect of Unemployment on Economic Growth in South Africa (1994-2016). Munich Personal RePEc Archive, No. 85305. Available online: https://mpra.ub.unimuenchen.de/85305/ (accessed on 30 December 2019).

Makris, Ilias A., and Stavros Stavroyiannis. 2019. Short and long-run linear and nonlinear causality between FDI and GDP for the US. International Journal of Economics and Business Research 18: 466-79. [CrossRef] 
Michael, Eze Onyebuchi, Atuma Emeka, and Egbeoma Nwigboji Emmanuel. 2016. The Relationship between Unemployment and Economic Growth in Nigeria: Granger Causality Approach. Research Journal of Finance and Accounting 7: 30-47.

National Treasury. 2019a. Economic Overview; Pretoria: Government Publications.

National Treasury. 2019b. Available online: http://www.treasury.gov.za/comm_media/press/2019/Towards\%20an\% 20Economic\%20Strategy\%20for\%20SA.pdf (accessed on 4 December 2019).

Nikensari, Sri I., Purbayo B. Santosa, and Fat X. Sugiyanto. 2019. Economic stagnation in emerging market countries: Should this justify Keynes's law? International Journal of Economic Policy in Emerging Economies 12: 299-314. [CrossRef]

Ramudo, Roberto B., Manuel F. Grela, and Doleros R. Garcia. 2014. Consumption, investment and unemployment: SVAR tests of the effects of changes in the consumption-saving pattern. Cogent Economics E Finance 2: 933676. [CrossRef]

Sahnoun, Marwa, and Chokri Abdennadher. 2019. Causality Between Inflation, Economic Growth and Unemployment in North African Countries. Economic Alternatives, University of National and World Economy 1: 77-92.

Sahoo, Malayaranjan, and Jayantee Sahoo. 2019. The relationship between unemployment and some macroeconomic variables: Empirical evidence from India. Theoretical and Applied Economics 16: 115-28.

Saungweme, Talknice, Simeone Matsvai, and Rose C. Sakuhuni. 2019. Econometric analysis of unemployment, output and growth of the informal sector in Zimbabwe (1985-2013). International Journal of Economics Research v5i2: 1-9.

South Africa History Online. 2019. Society and Politics. Available online: https://www.sahistory.org.za/ (accessed on 1 November 2019).

Statistics South Africa. 2018. Category Archives: Economic Growth. Available online: http://www.statssa.gov.za/ ?cat $=30$ (accessed on 31 October 2019).

Statistics South Africa. 2019. Economic Data Base. Available online: http://www.statssa.gov.za/ (accessed on 16 July 2019).

Suleiman, Salim Hamad, Safia Tafana Kassim, and Issa Moh'd Hemed. 2017. Unemployment and Economic Growth in Tanzania. Journal of Economics, Management and Trade 20: 1-8. [CrossRef]

Taraki, Sultan Ahmad, and Mesut Murat Arslan. 2019. Capital Formation and Economic Development. International Journal of Science and Research 8: 772-80.

Todaro, Michael P., and Stephen C. Smith. 2006. Economic Development, 8th ed. Reading: Addison-Wesley.

Wong, Mei F., Chang K. Fai, Yong C. Yee, and Lum S. Cheng. 2019. Macroeconomic policy and exchange rate impacts on the foreign direct investment in ASEAN economies. International Journal of Economic Policy in Emerging Economies 12: 1-10. [CrossRef]

World Bank. 2019. Unemployment, Total (\% of Total Labor Force). Available online: http://data.worldbank.org/ indicator (accessed on 3 November 2019).

Yoshino, Naoyuki, Tetsuro Mizoguchi, and Farhad Taghizadeh-Hesary. 2019. Optimal fiscal policy rule for achieving fiscal sustainability: The Japanese case. Global Business and Economics Review 21: 156-73. [CrossRef]

(C) 2020 by the authors. Licensee MDPI, Basel, Switzerland. This article is an open access article distributed under the terms and conditions of the Creative Commons Attribution (CC BY) license (http://creativecommons.org/licenses/by/4.0/). 